Historia Slavorum Occidentis

2020, nr 1 (24)

ISSN 2084-1213

DOI: $10.15804 /$ hso200101

Tomasz Graff (KraKów)

ORCID 0000-0002-2142-086X

\title{
A usurper with a crosier? The winding paths of the ecclesiastical career of Bohemian Carmelite Świętosław, the first Catholic Bishop of Euck (1404-ca. 1410)
}

Słowa kluczowe: biskup łucki Świętosław, polityka kościelna Władysława Jagiełły i Witolda na Rusi, metropolia halicka, późnośredniowieczny episkopat monarchii jagiellońskiej

Keywords: Świętosław Bishop of Łuck, Władysław Jagiełło and Witold’s ecclesiastical policy in Ruthenia, Halicz Metropolis, late-medieval episcopate of the Jagiellonian monarchy

Abstract: The article analyses the career of Bohemian Carmelite monk Świętosław, the first Catholic Bishop of Łuck. His appointment destabilized the situation in Volhynia in the early $15^{\text {th }}$ century. The author seeks to determine the identity of Świętosław's patron.

To date, historiography has not given too much attention to Świętosław, a $14^{\text {th }}-15^{\text {th }}$ century Carmelite brother and the first bishop of Euck (Lutsk). He was seen either as a Czech or a Pole who became Bishop of Euck in 1404 thanks to king Władysław Jagiełło's patronage. Most scholars investigating this issue maintained that this had undermined the plans which Grand Duke Witold (Vytautas the Great) harboured in relation to the Church in Volhynia. Witold was the actual founder and protector of what had until then been a titular bishopric. Witold was to be supported in his policy by Grzegorz Buczkowski Bishop of Włodzimierz (Volodymyr) (1400-ca. 1425), to whom Świętosław's preconisation meant an open ecclesiastical conflict 
in Volhynia. In a broader perspective, the conflict was interpreted as a dispute between Poland and Lithuania over ecclesiastical influence in this part of Ruthenia. Grzegorz Buczkowski was usually seen as Witold's collaborator and an advocate of Volhynia's independence from the Archbishop of Halicz (Halych) (Archbishop of Lwów from 1412). Meanwhile, by publicly demonstrating his subordination to Jakub Strepa Archbishop of Halicz, Świętosław was supposed to represent Polish interests. Researchers have also pointed out that the dispute between the bishops of Włodzimierz and Łuck was raised at the council held in 1409 in Pisa, attended in person by Bishop Buczkowski. At that time, Pope Alexander V requested Piotr Wysz, Bishop of Krakow, to solve the conflict between the two Volhynian ordinals. Historians even suggest that the Wysz's judgement was entered in favour Grzegorz or assume that Świętosław, in futile anticipation of the ruling to be issued by the Bishop of Krakow, died soon after the events, as evidenced in his absence from sources dating to subsequent years, during which Grzegorz Buczkowski’s activities were recorded in many documents ${ }^{1}$.

1 W. Abraham, Buczkowski Grzegorz, [in:] Polski Stownik Biograficzny [henceforth: PSB], editor: W. Konopczyński, Vol. 3, Krakow 1937, pp. 86-87; idem, Z dziejów dawnego biskupstwa w Łucku, Kwartalnik Historyczny, 51 (1937), Vol. 1-2, pp. 143-144; idem, Jakub Strepa arcybiskup halicki, Krakow 1908, pp. 54-57, 110, App. X; idem, Udziat Polski w soborze pizańskim (1409 r.), Rozprawy Akademii Umiejętności Wydz. Hist.-Filoz., 47 (1905), pp. 148-149; Dzieje Kościoła $w$ Polsce, ed. A. Wiencek, Krakow 2008, pp. 147; J. Drabina, Papiestwo - Polska w latach 1384-1434, Krakow 2003, pp. 38-39; J. Fijalek, Biskupstwa wolyńskie Polski i Litwy w swych początkach, “Sprawozdanie Akademii Umiejętności, Wydz. Hist.-Filoz., za kwiecień 1911”, Krakow 1912, pp. 20-21; T. Graff, Episkopat monarchii jagiellońskiej w dobie soborów powszechnych XV wieku, Krakow 2008, pp. 63-65, 72, 166, 193, 195; idem, Kariera, pochodzenie spoteczne i wyksztatcenie episkopatu metropolii lwowskiej (do 1412 halickiej) w I. pot. XV wieku, Zeszyty Naukowe Uniwersytetu Jagiellońskiego. Prace Historyczne, Vol. 133 (2006), pp. 37-38; Historia Kościota $w$ Polsce, eds. B. Kumor, Z. Obertyński, Vol. I: do roku 1764, Part I: do roku 1506, Poznan-Warsaw 1974, pp. 397-398; S. Kijak, Pior Wysz biskup krakowski, Krakow 1933, pp. 54-55; B. Kumor, Historia Kościoła, IV: Jesień Kościelnego Średniowiecza, Lublin 2001, p. 136; idem, Początki metropolii wileńskiej, Studia Teologiczne, 5-6 (1987-1988), pp. 76-77; idem, Organizacja diecezji litewskich do końca XV wieku, [in:] Chrzest Litwy. Geneza. Przebieg. Konsekwencje, editor: M.T. Zahajkiewicz, Lublin 1990, pp. 79-80; J. Kumor-Mielnik, Świętostaw, [in:] Encyklopedia Katolicka, Vol. XIX, ed. E. Gigilewicz, Lublin 2013, col. 400; M. Malinowski, B. Kołosok, Zarys dziejów diecezji tuckiej oraz katedry Św. Piotra i Pawła w Łucku, Kalwaria Zebrzydowska 1993, p. 15; J. Nikodem, Witold. Wielki Ksiażę Litewski (1354 lub 1355 - 27 października 1430), Krakow 2013, p. 439; P. Nitecki, Biskupi Kościoła w Polsce w latach 965-1999. Stownik biograficzny, Warsaw 2000, col. 440; K.R. Prokop, Biskupi pomocniczy w diecezjach polskich $w$ dobie przedtrydenckiej, Krakow 2002, pp. 340-341; idem, Sylwetki biskupów łuckich, Biały Dunajec 2001, pp. 22-29; Z. Szostkiewicz, Katalog biskupów obrządku łacińskiego przedrozbiorowej Polski, [in:] Sacrum Poloniae Millenium. 
The historiographic views outlined above have since become largely outdated, or at the very least profoundly questioned, when in 1997 Grażyna Klimecka published the so-called Formularz Ciechanowski, containing a letter hitherto unknown to researchers, written by Władysław Jagiełło to, as Klimecka believed, one of Pisan popes in 1410. In the letter, the king called Świętosław a usurper who had illegally seized the Łuck bishopric ${ }^{2}$. The monarch's words profoundly undermined the above hypothesis that Świętosław had allegedly received the bishopric owing to Jagiełło's influence. The letter seems to overturn the entire narrative structure concerning the role of the bishop in the Polish-Lithuanian dispute over the shape of the ecclesiastical organisation in Ruthenia, in particular in Volhynia. Quite importantly, with the exception of biographical entries in Polski Stownik Biograficzny (entries: Strepa Jakub and Swiętosław $)^{3}$, the letter has not been used so far in publications analysing the situation of the Church in Ruthenia in the early $15^{\text {th }}$ century. Moreover, since most historians accepted Jagiełło's patronage as a fact and the main reason for Świętosław's appointment as Bishop of Łuck, nobody has yet attempted to find other causes of the event. For a long time researchers have struggled to interpret the series of events described above, which was best expressed by Władysław Abraham who called it "a dark and quite mysterious matter", and described Świętosław as "some nondescript personage"4

Rozprawy - Szkice - Materialy historyczne, Vol. 1, Rome 1954, pp. 568, 603; T.M. Trajdos, Kościót katolicki na ziemiach ruskich Korony i Litwy za panowania Władystawa Jagietly (1386-1434), Vol. 1, Wrocław 1983, pp. 78-79, 145, 222; idem, U zarania Karmelitów w Polsce, Warsaw 1993, pp. $216-$ -217; idem, Fundacja klasztoru karmelitów trzewiczkowych na Piasku w Krakowie, Nasza Przeszłość, 60 (1983), pp. 125-126; idem, Polityka Władysława II Jagietty wobec Kościoła Katolickiego na ziemiach ruskich Królestwa Polskiego i Wielkiego Księstwa Litewskiego, Zeszyty Naukowe Uniwersytetu Jagiellońskiego. Prace Historyczne, 141 (2014), Vol. 2, p. 333; idem, Dominikanie i franciszkanie na ziemiach ruskich Korony Polskiej i Wielkiego Księstwa Litewskiego wobec władzy państwowej za panowania Wtadysława II Jagietly, [in:] Klasztor w państwie średniowiecznym i nowożytnym, eds. M. Derwich, A. Pobóg Lenartowicz, Wrocław-Opole-Warsaw 2005, pp. 438-440; M. Wilamowski, Strepa Jakub, PSB, Vol. 44, Warsaw-Krakow 2006-2007, p. 320; I. Wysokiński, Kościót taciński na ziemiach ruskich Korony i Litwy w początkach panowania Jagiellonów, Przegląd Historyczny, 76 (1985), Vol. 3, pp. 551-552. More recently, information about Świętosław was compiled in a dictionary entry by T. Graff, Świętosław (zm. ok. 1410), karmelita, kapelan papieski, bp łucki, PSB, Vol. 51, Krakow 2017, pp. 547-549.

2 G. Klimecka, Z historii tworzenia języka dokumentu polskiego wieków średnich. Formularz ciechanowski, Warsaw 1997, No. 25, pp. 84-85; cf. eadem, Nieznane źródło do historii kultury XV wieku. Próba określenia proweniencji i identyfikacji autora, Muzyka, 4 (1992), p. 85.

3 M. Wilamowski, Strepa Jakub, p. 320; T. Graff, Świętosław, p. 548.

4 W. Abraham, Udziat Polski w soborze pizańskim, p. 148. In our opinion, Abraham mistook Świętosław for a clerk of the royal chancery of Casimir III the Great during the years 1368-1369 
The present publication is thus another attempt to explain Świętosław's ecclesiastical career path which led him to the Euck cathedral - based on the letter from Formularz Ciechanowski - and to present his career in the context of the Church's position in the Volhynia region.

What do we know for certain about Świętosław and his ecclesiastical career? Not much: on 15th November in Perusia he was named Chaplain of His Holiness by Pope Boniface IX who extolled his virtues (virtutibus clarens). In addition, the deed of pontifical appointment states that Świętosław, son of Jarosław, was a Carmelite at that time ${ }^{5}$. The monk had presumably had connections with the Prague or Tachov monastery for some time, and his title of the Chaplain of His Holiness testifies to his descent from a prestigious and influential Bohemian family, or at least patronage of such a family. Alternatively, he may have received this support from a Bohemian ecclesiastical hierarch, e.g. Jan of Jenštejn, Archbishop of Prague (1379-1396) ${ }^{6}$, or even from the Royal House of Luxembourg. Also, his previous merits in Christian missions, perhaps in Ruthenia and Lithuania, cannot be entirely excluded.

In addition to the above considerations, it is difficult to determine the year when Świętosław received his presbyterial orders. Unfortunately, records of ordinations in the Prague diocese contain entries from the years 1395-1416, and these data originate chronologically from the time when Świętosław had already been a monk for

merely on the basis of the identical names referred to [in:] Kodeks Dyplomatyczny Matopolski, Vol. 3, published by F. Piekosiński, Krakow 1887, No. 817; Zbiór dyplomów klasztoru mogilskiego przy Krakowie, published by E. Janota, Krakow 1865, No. 84.

5 Monumenta Vaticana res gestas Bohemicas illustrantia, sumptibus comitiorum regni Bohemiae ediderunt ad recensendos historiae Bohemicae fontes delegati, V: Acta Urbani VI et Bonifatii IX. 1378-1404, ed. C. Krofta, Prague 1903-1905, No. 649, p. 367; Bullarium Poloniae [henceforth: BP], Vol. 3:1378-1417, ed. I. Sułkowska-Kurasiowa, S. Kuraś, Romae-Lublini 1988, No. 319, p. 55.

6 S. Seifert, Z. Hledíková, Johann von Jenstein (1347/50-1400). 1376-1378 Bischof von Meißen. 1378-1396 Erzbischof von Prag. 1399-1400 Patriarch von Aquileja, [in:] Die Bischöfe des Heiligen Römischen Reiches 1198 bis 1448. Ein biographisches Lexikon. Bd. 1, Berlin 2001, pp. 590-592; J. Ježek, Jan z Jenšteina. Třetí arcibiskup Pražský, Prague 1900; R.E. Weltsch, Archbishop John of Jenstein (1348-1400). Papalism, Humanism and Reform in Pre-Hussite Prague, Paris 1968; W. Eberhardt, Jenstein, Johann von, [in:] Neue Deutsche Biographie, 10 (1974), pp. 410-411; R. Holinka, Církevní politika archbiskupa Jana z Jenštejna za pontifikátu Urbana VI, Bratislava 1933; J.V. Polc, Giovanni di Jenstejn, Bollettino dell'Istituto Storico Ceco di Roma, 3 (2002), pp. 3-20; P. Rychterová, Charisma und charismatische Legitimation in der Vita von Johannes von Jenstein, [in:] Kunst als Herrschaftsinstrument. Böhmen und das Heilige Deutsche Reich unter den Luxemburgern im europäischen Kontext, cur. J. Fajt, Berlin 2009, pp. 346-353; A. Frind, Die Geschichte der Bischöfe und Erzbischöfe von Prag, Prague 1873, pp. 101-106. 
at least several years. Nevertheless, it is worth noting that in the light of the source the name Świętosław was fairly popular in Bohemia ${ }^{7}$. Furthermore, after a year of novitiate in the Carmelite order, Świętosław probably became a votary during his teenage years (minimum at 14) or even a few years later than at the age of twenty. Nevertheless, this must have happened prior to $15^{\text {th }}$ November 1392, i.e. the day on which he was conferred the title of the Chaplain of His Holiness, under which he was first attested as a votary in the Carmelite Order ${ }^{8}$. In any event, he may have been born around 1360/70 and joined the order in the Prague Church of Our Lady of the Snows, the prior of which in the years 1391-1395 was a man named Hartman'.

Initially, Świętosław must have connected his further ecclesiastical career path to the Kingdom of Bohemia, more specifically the Prague archdiocese, because he vigorously and successfully competed for lay prebends in the archdiocese, explicitly supported by pope Boniface IX and the Curia. Świętosław's connections in the Holy See only reinforce our conjecture that he was not a regular monk but probably quite an important person in the Bohemian church community. On $28^{\text {th }}$ May 1399 the pope wrote a letter from Rome to the Bishop of Nicopolis - a titular Auxiliary Bishop of Prague, to the abbot of the church at the Apostles' Gate in the Prague diocese and to the Hradec Archdeacon, stating that due to his devotion shown to the pope and the Holy See, Świętosław deserved a generous reward. The recipients of the papal letter (clerics linked to Prague) were not selected randomly ${ }^{10}$. The pope was trying to prove that as a consequence of Jakub of Tachov's resignation, the parish church in Radčice (German Maria Ratschitz, currently Mariánské Radčice), a part of the abbot's patronage and of the Cistercian monastery in Osek, had a vacancy, and that Świętosław should be granted the benefice. He also made a reservation that Świętosław, being a monk, had received a dispensation to manage the church estimated at 4 hrivnas of silver per annum, like a secular cleric together with cura animarum ${ }^{11}$. It transpires,

\footnotetext{
7 E. Doležalová, Svěcenci pražské diecéze 1395-1416, Prague 2010, p. 123.

8 T. Graff, Świętostaw, pp. 547-549.
}

9 Dějepis města Prahy, Vol. V, ed. V.V. Tomek, Prague 1881, p. 217 (contains also Czech and German names of other Carmelite monks of the period. Some of the monks may have arrived in Poland at the invitation of Queen Jadwiga and King Władysław Jagiełło).

10 At that time, Dominican friar Wenceslaus de Applot was the Auxiliary Bishop of Prague: C. Eubel, Hierarchia Catholica Medii Aevii, Vol. 1, Monasterii 1913, p. 364; Dějepis města Prahy, Vol. V, ed. V.V. Tomek, Praha 1881, p. 115; E. Doležalová, Svěcenci pražské diecéze 1395-1416, p. 113.

11 Monumenta Vaticana res gestas Bohemicas illustrantia, No. 1466. 
however, that despite the pontifical support Świętosław could not easily receive the privilege, since a Mikołaj of Lubań, who claimed to be a priest from the Meißen diocese, also expressed interest in the prebend. Mikołaj took the church in Radčice by force and had no intention of allowing Świętosław to take over. These facts are provided in Pope Boniface IX's document of 28th June 1401 in which the pope instructed pontifical auditor Leonard of Sulmona to resolve the dispute between the two clergymen. Had he come to the conclusion (already shared by some) that neither Mikołaj of Lubań nor Świętosław were entitled to the church in Radčice, he should have decided in favour of the latter ${ }^{12}$. Thus, the document is yet another proof of a truly extraordinary benevolence of Pope Boniface IX towards Świętosław. Indeed, the pope clearly stated that Świętosław's religious piety, virtuous life and commendable conduct implicated the need of reward, and that Świętosław, presumably wellknown to the Curia, had expressly requested the matter to be forwarded to the Holy $\mathrm{See}^{13}$. Clearly, in 1401 Świętosław was intensely preoccupied with the dispute (which had already lasted for 2 years) over the prebend in the Prague diocese. As the pope himself emphasized, on an annual basis it yielded 4 hrivnas of silver at the most. It seems that hitherto he had had no relations with the Polish royal court, the recently deceased Queen Jadwiga, Jagiełlo or Witold - if, as clearly stated above - his function as the Chaplain of His Holiness had not been previously connected with some Christian mission on the territory of the Polish-Lithuanian monarchy. Świętosław, son of Jarosław, probably did not come with other Carmelites from Bohemia to Poland, or to the king's seat in Krakow, or to Poznań, Bydgoszcz. However, this possibility may not be entirely excluded. In the light of the above biography it is more likely that he was of Czech rather than Polish descent as suggested by Tadeusz Trajdos who called Świętosław a Polish Carmelite (although, as we know, Poles from the Crown and Silesians from the duchies annexed the Luxembourg were furthering their ecclesiastical careers also in Bohemia, and the criterion of nationality in those cases is highly doubtful $)^{14}$. In any case, it makes more sense to call him a Czech Carmelite, in that for years he had ties with the Bohemian monastery in Prague (which is more likely)

\footnotetext{
12 Ibidem, No. 1805.

13 Ibidem.

14 T.M. Trajdos, Kościót katolicki na ziemiach, p. 78; idem, U zarania Karmelitów w Polsce, p. 217; idem, Fundacja klasztoru karmelitów, p. 125-126; idem, Polityka Władysława II Jagietty, p. 333; cf. W. Abraham, Z dziejów dawnego biskupstwa w Łucku, pp. 143-144; T. Graff, Kariera, pochodzenie społeczne i wyksztatcenie episkopatu metropolii lwowskiej, p. 38 (here a conjecture that Świętosław was Czech).
} 
or Tachov. Even if he had appeared in Poland with a group of newly arrived monks or joined such a group, he soon left the Krakow or Poznań monastery due to his position in the Euck diocese in 1404.

Indeed, the most intriguing fact in Świętosław's ecclesiastical career was the start of his incumbency in the Euck diocese as the first Bishop of Łuck in history. Interestingly, the situation did not require establishment of a new diocese, as the Eastern Orthodox diocese of Łuck had already existed. Accordingly, according to Rome the Latin diocese had the same territory and the Eastern Orthodox bishop already held the position of a usurper and a schismatic ${ }^{15}$. On the other hand, the acts coincided with the Polish court's plans for a union which practicably had no chance of success $^{16}$.

Pope Boniface IX, to whom Świętosław owed all of his ecclesiastical career, preconised him as the Bishop of Euck on $12^{\text {th }}$ May $1404^{17}$. Interestingly, in his preconisation bull the Holy Father called him 'bishop elect' although no election by the Euck chapter was possible, as none such body existed. The pope motivated his decision, made presumably in consultation with cardinals, in a characteristic way, i.e. by stating that the Euck church had so far been deprived of pastoral care and the vacancy had existed for so long that the period of vacancy was actually unknown. Hence his following statement:

"following meticulous deliberations with our brothers on the appointment of a useful and beneficial person as the head of this Church, we turned our

15 Vetera Monumenta Poloniae et Lithuaniae gentiumque finitimarum historiam illustrantia [henceforth: Theiner], Vol. 1, ed. A. Theiner, Romae 1860, No. 964; Relationes status dioecesium in Magno Ducatu Lituaniae, ed. P. Rabikauskas, Vol. 2, Rome 1978, pp. 5-6; T.M. Trajdos, Kościót katolicki na ziemiach, p. 78. On the situation of East Orthodox Christians under Piast and Jagiellonian monarchies: O. Halecki, Od unii florenckiej do unii brzeskiej, Vol. 1-2, Lublin 1997; A. Mironowicz, Kościót prawostawny w państwie Piastów i Jagiellonów, Białystok 2003.

16 A. Mironowicz, Kościót prawosławny, pp. 145-153; T.M. Trajdos, Biskupi prawosławni w monarchii Jagietty, Nasza Przeszłość, 66 (1986), pp. 10-157; idem, Metropolici kijowscy Cyprian i Grzegorz Camblak a problemy Cerkwi prawosławnej w państwie polsko-litewskim u schyłku XIV i w pierwszej ćwierci XV w., Balcanica Posnaniensia, 2 (1985), pp. 211-234; A. Lewicki, Sprawa unii kościelnej za Jagietty, Kwartalnik Historyczny, 11 (1897), pp. 310-337. In 1404 Cyprian, Metropolitan of Kiev, assisted by the bishops of Łuck and Chełm, consecrated Iwan Hohola Bishop of Włodzimierz and Volhynia, and, at the request of Witold, imprisoned Antoni, Bishop of Turov.

17 Monumenta Vaticana res gestas Bohemicas illustrantia, No. 2197; BP, Vol. 3, No. 951; C. Eubel, Hierarchia Catholica Medii Aevii, Vol. 1, p. 314. 
minds' eyes to you, a votary of the Order of the Brothers of the Blessed Virgin Mary of Mount Carmel, recipient of the Holy Orders... and, considering everything in due contemplation, acting out of care for this Church and upon the advice of the said brothers, we nominate you its bishop and pastor" [translation] ${ }^{18}$.

Boniface also emphasised Świętosław's duty of residence in the Euck diocese, leaving no doubt that it was not titular:

"We would like you - as soon as you receive this letter - to move to the said Church and personally reside in it, and you cannot perform your duties as the bishop outside Euck or the Euck diocese" [translation] ${ }^{19}$.

The papal document did not name any external factor which could have triggered Świętosław's appointment to the Łuck bishopric; in fact, the pope suggested that the decision had been taken solely by him and his advisers. Was it really the case?

Let us consider the following possibilities:

a) a deliberate action on the part of the pope who (in spite of the prerogatives of Grzegorz Buczkowski, Archbishop of Włodzimierz) decided to demonstrate the power of his ecclesiastical policy towards the Polish-Lithuanian monarchy, and nominate a trusted chaplain on Euck in Ruthenia without Jagiełło or Witold's approval;

b) the pope's and other officials' lack of understanding of the Church's position in Ruthenia and favouring external factors related to Bohemian elites or Wenceslaus IV's royal court;

c) the pope's bias towards Świętosław as Jagiełło's candidate for the Łuck bishopric without considering the interest of Duke Witold and his protégée Grzegorz Buczkowski. In this case we must assume that several years later in his letter to the Pisan pope, Jagiełło deliberately lied, calling the Bishop of Łuck a usurper.

\section{Which of the above scenarios is more likely?}

The first one would indicate that Boniface IX strove to build the Church's structures in Ruthenia without cooperation with the Polish king and against Witold's will As such, this scenario seems the most far-fetched. In the light of the practice of episcopal nominations in Poland-Lithuania, as well as the trends prevailing across Europe

Monumenta Vaticana res gestas Bohemicas illustrantia, No. 2197. 
(e.g. Gallicanism), another attempt at papal interference in internal ecclesiastical matters of the Jagiellonian monarchy seems very imprudent ${ }^{20}$. It would have not only been made without Jagiełło's consent but also without the consent of Witold (whose authority extended over Volhynia), the actual founder and benefactor of the Włodzimierz bishopric, headed since 1400 by the first non-titular hierarch Grzegorz Buczkowski, having jurisdiction also over the Łuck region. Still, even if the pope was ignorant of the location of Łuck, he must have been aware of the person who claimed to be the lord of the town. This is corroborated by the fact that as soon as in 1398, he had addressed Witold as the Duke of Lithuania and lord of Euck (Alexandro dicto Witholdo, duci Lythwaniae et domino Luczensi) ${ }^{21}$. In any case, this move on the part of the pope who established the Euck diocese and appointed Świętostław its bishop without consulting the Gediminids, must have meant an open conflict with Poland and Lithuania. This was very inconvenient for the Holy See due to the protracted Western Schism and concerns that Poland might ultimately refuse to submit to the Roman authority. Anyway, Boniface IX must have clearly remembered his own altercations with the Polish court over the episcopal appointments; it was him who, against Jagiełło and Jadwiga's will, attempted to push his candidates for the Crown's most important episcopal sees, consistently rejecting - as best exemplified by Gniezno Archbishop Dobrogost ${ }^{22}$ and Krakow Bishop Piotr Wysz ${ }^{23}-$

20 For more details, see T. Graff, Episkopat, passim.

21 BP, Vol. 3, No. 520.

22 Ibidem, No. 357; Codex epistolaris saeculi decimi quinti, Vol. 1, eds. A. Sokołowski, J. Szujski, Cracoviae 1876, No. 24; Joannis Dlugossii Annales seu Cronicae incliti Regni Poloniae, lib. 0: 1370-1405, ed. S. Gawęda et al., Varsaviae 1985, pp. 207-208; Ioannis Dlugossii Vitae Episcoporum Poloniae, ed. I. Polkowski, Ż. Pauli, [in:] Opera Omnia, Vol. 1, Cracoviae 1887, p. 366; W. Abraham, Sprawozdanie z poszukiwań $w$ archiwach I bibliotekach rzymskich do dziejów Polski w wiekach średnich za lata 1899-1913, Archiwum Komisji Historycznej AU, Series II, Vol. 1, Krakow 1923, p. 25; T. Graff, Episkopat, p. 156; S. Trojanowski, Dobrogost, PSB, Vol. 5, Krakow 1939-1946, p. 246.

23 Biblioteka Jagiellońska, MS 461, f. 154v; BP, Vol. 3, No. 320; Kodeks dyplomatyczny katedry krakowskiej św. Wactawa, Part 2, issued by F. Piekosiński, Krakow 1883, No. 390; Joannis Dlugossii Annales seu Cronicae incliti Regni Poloniae, lib. 10, p. 499; Najdawniejsze roczniki krakowskie i kalendarz, issued by Z. Kozłowska-Budkowa, [in:] Monumenta Poloniae Historica, Series II, Vol. 5, Warsaw 1978, pp. 112-113; Ioannis Dlugossii Vitae Episcoporum Poloniae, pp. 419-420; S. Kijak, Pior Wysz biskup krakowski, p. 12; W. Seńko, Piotr Wysz z Radolina i jego dzieło "Speculum Aureum", Warsaw 1996, pp. 296-297; S. Trawkowski, Piotr z Radolina, PSB, Vol. 26, Krakow-Wroclaw 1981, pp. 422-428; K. Ożóg, Spór o biskupstwo krakowskie w roku 1392 na tle stosunków Polski z papiestwem u schytku XIV wieku, Kwartalnik Historyczny, 104 (1997), No. 1, 
successful candidates for the bishop's mitre supported by the Polish royal couple ${ }^{24}$. Chronicler Jan Dlugosz admitted that the pope's concession in this area resulted from his concerns that "the Polish king Władysław, if his wishes were disregarded, could go over to the side of antipope Pedro de Luna"25. Three years before Świętosław's preconisation, in a letter to nuncio Anthony, the same pope expressed his doubts concerning Poland's loyalty and its lasting obedience to the Holy $\mathrm{See}^{26}$.

Is it possible that the pope risked so much and, despite lack of Jagiełlo and Witold's consent, insisted on supporting Świętosław - the bishop of a low-prestige diocese established in hazy circumstances? He probably did not do it on purpose unless we assume that it was yet another attempt at showing Jagiełlo that the Polish king still had to reckon with pontifical prerogatives concerning the personal composition of the local episcopacy (perhaps hoping that the monarch's stance would not be as firm as in the case of the archbishopric of Gniezno and the bishopric of Krakow) ${ }^{27}$. However, this solution would suggest the Roman Curia's lack of foresight as to the results of the pope's decision in respect of a minor bishopric, a decision that shifted the balance of competing ecclesiastical forces between Poland and Lithuania in the region of Volhynia and undermining the position of Witold's favourite, Grzegorz

p. 3.19; idem, Maffiolus Lampugnani nominat na biskupstwo krakowskie, biskup płocki: meandry kariery kurialisty rzymskiego w okresie schizmy zachodniej, Roczniki Humanistyczne, 48 (2000), Vol. 2, pp. 345-367; idem, Kurozwęccy a spór o biskupstwo krakowskie w roku 1392, Zeszyty Naukowe Uniwersytetu Jagiellońskiego. Prace Historyczne, Vol. (123) 1997, pp. 57-74; idem, Kościót krakowski wobec wielkiej schizmy zachodniej, p. 31; idem, Duchowni i uczeni w otoczeniu św. Jadwigi, [in:] Święta Jadwiga Królowa. W perspektywie III Tysiąclecia, Krakow 2002, pp. 168-169; J. Drabina, Papiestwo - Polska, pp. 30-31; T. Graff, Episkopat, pp. 157-158.

24 On Jadwiga and Jagiełło's common and unanimous policy towards the Church, see T. Graff, Osobowość Jadwigi Andegaweńskiej w świetle kontaktów Polski ze Stolica Apostolską w okresie schizmy zachodniej w latach 1388/9-1399, [in:] Świat kobiet w Czechach i w Polsce w średniowieczu $i$ w epoce nowożytnej, eds. W. Iwańczak, A. Januszek-Sieradzka, J. Smolucha, Krakow 2018, pp. 536-556; cf. J. Nikodem, Jadwiga król Polski, Wrocław 2009, pp. 360-362.

25 J. Długosz, Roczniki czyli Kroniki sławnego Królestwa Polskiego, Book 10: 1370-1405, ed. S. Gawęda et al., Warsaw 2009, pp. 271-272.

26 T. Graff, Episkopat, p. 158; idem, Osobowość Jadwigi Andegaweńskiej, p. 550; W. Seńko, Piotr Wysz, p. 71; W. Abraham, Udział Polski w soborze pizańskim 1409, p. 127.

27 For information on the state policy concerning episcopal appointments at that time, see R.L. Benson, The Bishop-Elect. A Study in Medieval Ecclesiastical Office, New Jersey 1968; P. Linden, Der Tod des Benefiziaten im Rom. Eine Studie zu Geschichte und Recht der päpstlichen Reservationen, Bonn 1938. 
Buczkowski (Bishop of Włodzimierz) who did not wish to submit himself to Archbishop Jakub Strepa, a representative of Polish influences.

While the very first scenario: an attempt to arbitrarily appoint Świętosław the Bishop of Łuck, implying the pope's deliberate action from the very beginning is likely, it raises many doubts and it seems that Boniface IX would not have taken this risk without consulting his decision with the Polish and Lithuanian courts.

The second possibility, explaining Świętosław's nomination as the Bishop of Łuck, suggests that the Holy See could actually have had a poor understanding of the Church's situation in distant Ruthenia. For some time, the region had also been the subject of claims for jurisdiction brought by bishops of Lubusz, all the more so that for decades Ruthenia had seen shifts in power due to clashes among the Gediminids. As early as in 1375, Pope Gregory XI, rejected the claims voiced by bishops of Lubusz, established the Metropolis of Halicz and subordinated the bishops of Przemyśl, Włodzimierz and Chełm to the Archbishop of Halicz ${ }^{28}$. Meanwhile, the pope asked the Archbishop of Gniezno and bishops of Krakow and Płock if the Kiev, Turov and Łuck churches were kathedrales an parochiales ${ }^{29}$. Moreover, at the same time, at the request of Duke Władysław Opolczyk, the pope plied the very same hierarchs with questions if it was better to move the capital of the archdiocese from Halicz to Lwów, a place better known and safe behind city walls ${ }^{30}$. On the other hand, it its rather unlikely that nearly 30 years later no-one from Boniface IX's circle realised that Łuck fell within Witold's authority. As discussed above, in 1398 it was Boniface IX who bestowed upon Witold the title of the Duke of Lithuania and ruler of uuck $^{31}$. Presumably, the Curia was also aware that Świętosław's nomination for the bishopric without the agreement of the Lithuanian duke would meet with his firm resistance. Resistance on part of the Bishop of Włodzimierz, who headed the diocese in which Łuck was located, was also to be expected. Notably, in 1400 it was Grzegorz Buczkowski, at that time still prior of the Łuck Dominicans, who entreated Rome for his preconisation in the Włodzimierz bishopric, probably shedding light on the Church's position in Volhynia ${ }^{32}$. However, for pontifical officials and the pope

28 BP, Vol. 2, ed. I. Sułkowska-Kurasiowa, S. Kuraś, Romae 1985, No. 2200; Theiner, Vol. 1, Nos. 963-964.

29 BP, Vol. 2, No. 2203; Theiner, Vol. 1, No. 966; cf. Relationes status dioecesium in Magno Ducatu Lituaniae, p. 6.

30 BP, Vol. 2, No. 2201, 2209; Theiner, Vol. 1, No. 967.

31 BP, Vol. 3, No. 520: Alexandro dicto Witholdo duci Lythwaniae et domino Luczensi [...].

32 K.R. Prokop, Sylwetki biskupów tuckich, pp. 22-23. 
himself ecclesiastical matters in Ruthenia may have seemed rather remote and exotic. What is more, for a long time the Halicz archdiocese did not have any actual but merely titular bishops ${ }^{33}$. Namely, two consecutive bishops of Włodzimierz Hynek von Hasenburg (1371-1388) ${ }^{34}$ and Mikołaj (ca. 1390-1400) ${ }^{35}$ were in fact Archbishop of Prague's auxiliary bishops which is of significance in the light of the further discussion ${ }^{36}$. On the other hand, Stefan, Bishop of Chełm, was in fact Auxiliary Bishop of Poznań and Włocławek, and Jakub Strepa had to substitute for him in his diocese in administrative matters ${ }^{37}$. Clearly, two to three decades after the establishment of the Halicz Metropolis, right before Świętosław's incumbency of the Euck bishopric, the situation of the Church in Ruthenia was far from stable, and the local episcopate did not enjoy the political or economic influences of the bishops in the Kingdom of Poland ${ }^{38}$. In fact, Jakub Strepa, Archbishop of Halicz ${ }^{39}$, Maciej of Sandomierz, Bishop of Przemyśl ${ }^{40}$ and Grzegorz Buczkowski, the Włodzimierz or-

33 For more details, see W. Abraham, Początki arcybiskupstwa tacińskiego we Lwowie, Lwów 1909.

34 K.R. Prokop, Biskupi pomocniczy w diecezjach polskich, pp. 359-360. His predecessor, Dominican friar Piotr (deceased before 1371), who received the provision for the Włodzimierz bishopric from the Patriarchate of Constantinople before 1358, was in fact a suffragan of Gniezno. His first provision had not been accepted by Pope Innocent VI who granted it again in 1358 . See Ibidem, pp. 289-290.

35 Ibidem, pp. 364-365.

36 Relationes status dioecesium in Magno Ducatu Lituaniae, p. 5. The acts of Mikołaj Bishop of Włodzimierz as the Auxiliary Bishop of Prague, are evidenced in the Prague diocese's Records of Ordinations. See E. Doležalová, Svěcenci pražské diecéze 1395-1416, pp. 113-118; cf. Dějepis města Prahy, Vol. V, pp. 115-116 (here Mikołaj is also mentioned as an inquisitor).

37 A. Sochacka, Stefan, PSB, Vol. 43, Warsaw-Krakow 2004-2005, pp. 147-149; M. Wilamowski, Strepa Jakub, p. 320; T. Graff, Episkopat, p. 56; P. Czaplewski, Tytularny episkopat w Polsce .średniowiecznej, Roczniki Poznańskiego Towarzystwa Przyjaciół Nauk, 43 (1915), pp. 109-110. 38 W. Abraham, Powstanie organizacji Kościoła łacińskiego na Rusi, Vol. 1, Lwów 1904; J. Krętosz, Organizacja archidiecezji lwowskiej obrzadku łacińskiego od XV wieku do 1772 roku, Lublin 1986; cf. T. Graff, Episkopat, p. 105; idem, Kariera, pochodzenie spoteczne i wykształcenie episkopatu metropolii lwowskiej, pp. 31-41; idem, Precedencja biskupów metropolii gnieźnieńskiej i lwowskiej w I połowie XV wieku, Nasza Przeszłość, 102 (2004), pp. 105-150; J. Wiesiołowski, Episkopat polski XVw jako grupa społeczna, [in:] Społeczeństwo Polski Średniowiecznej, Vol. 4, Warsaw 1990, pp. 236-295.

39 W. Abraham, Jakub Strepa arcybiskup halicki, passim; M. Wilamowski, Strepa Jakub, pp. 318-324.

40 A. Strzelecka, Maciej, PSB, Vol. 19, pp. 9-10; W. Sarna, Biskupi przemyscy obrządku łacińskiego, Part 1, 1375-1624, Przemyśl 1903, pp. 31-40; F. Pawłowski, Series et gesta episcoporum premisliensum, Krakow 1870, pp. $73-86$. 
dinary ${ }^{41}$, were the only bishops residing in their dioceses. We may therefore hypothesize that the Roman Curia saw some grounds for Świętosław's nomination to the position of Bishop of Łuck without an in-depth analysis of the serious political implications. This could be also the case if we assume that the request for Świętosław's preconisation came from Bohemia (perhaps even from the court of Wenceslaus IV) and was intended to cause the conferral of the title of auxiliary bishop to Zbyněk Zajíc (Lupus) of Hasenburg, Archbishop of Prague (1402-1411), a close relative of Hynek of Hasnburg, an Augustinian monk and Bishop of Włodzimierz, deceased in $1388^{42}$. Since two auxiliary bishops of Prague, i.e. Hynek of Hasenburg and Mikołaj, were titular Bishops of Włodzimierz, and the Włodzimierz bishopric had in fact been held since 1400 by Grzegorz Buczkowski after Mikołaj's transition to the titular episcopal see Silivri (Selymbria) linked to the Constantinople patriarchate ${ }^{43}$, the Church both in Prague and in Rome may have come to the conclusion that it was the Euck diocese which could serve the same purpose as the Włodzimierz diocese-

41 W. Abraham, Buczkowski Grzegorz, p. 86-87; K. R. Prokop, Sylwetki biskupów tuckich, pp. 22-26. Remarkably, in 1409 Grzegory XII, when nominating Wojciech Jastrzębiec (Bishop of Poznań) Legatus a Latere, named among Polish dioceses, in addition to 6 bishoprics under the Metropolitan Bishop of Gniezno, only the Halicz archbishopric, as if the latter did not have any suffragan bishops. See Theiner, Vol. 1, No. 1056. We know equally little about the functioning of the Moldavian bishopric at that time. In 1405 Jan, the then Bishop of Moldova, a Franciscan, made his attestation in a document of Jakub Strepa Archbishop of Halicz issued to the Lwów Franciscans, like Aleksander Bishop of Kamieniec in the next year in a deed of gift concerning the donation of a chalice for the same monastery: W. Abraham, Jakub Strepa arcybiskup halicki, p. 107, Appendix VIII and p. 110, Appendix X. See also idem, Biskupstwa tacińskie w Mołdawii w wiekach XIV i XV, Kwartalnik Historyczny, 16:1902, pp. 172-207; idem, Aleksander, PSB, Vol. 1, Krakow 1935, p. 66; T.M. Trajdos, Kościót katolicki na Podolu (1340-1434), [in:] Kamieniec Podolski. Studia z dziejów miasta i regionu, Vol. 1, ed. F. Kiryk, Krakow 2000, p. 148; T. Graff, Episkopat, p. 60. Interestingly, as early as in 1406 Stefan, Bishop of Sereck and Grzegorz Bishop of Włodzimierz were in the Council of Kalisz in the Gniezno Metropolis. See the Diocesal Archive in Płock, Visit. 267, sheet 499r-500r; P. Simson, Geschichte der Stadt Danzig, Bd. 4, Danzig 1918, No. 119; Starodawne Prawa Polskiego Pomniki, published by. A.Z. Helcel, Vol. 1, Warsaw 1856, pp. 415-416; H. Likowski, Synod prowincjonalny kaliski z r. 1406, Przegląd Teologiczny, 6 (1925), pp. 377-390; I. Subera, Synody prowincjonalne arcybiskupów gnieźnieńskich. Wybór tekstów ze zbiorów Jana Wężyka z r. 1761, Warsaw 1981, pp. 68-69; T. Graff, Episkopat, pp. 115, 190.

42 Z. Hledíková, Zbynek Zajíc von Hasenburg (1376-1411). 1402-1411 Erzbischof von Prag, [in:] Die Bischöfe des Heiligen Römischen Reiches, 1, pp. 593-594; A. Frind, Die Geschichte der Bischöfe und Erzbischöfe von Prag, pp. 107-116.

43 K.R. Prokop, Biskupi pomocniczy w diecezjach polskich, p. 359 ff.; idem, Sylwetki biskupów tuckich, p. 22. 
without leading to a conflict with Witold. Perhaps the Bohemian influence on the episcopal appointments in Red Ruthenia was the aftermath of the Lubusz bishops' jurisdictional claims to Red Ruthenia which, despite Władysław Abraham's and Tadeusz M. Trajdos's views, did entirely expire during the pontificate of Jan Mráz and Jan Borschnitz. Interestingly, the hierarchs had close connections with Wenceslaus IV King of Bohemia ${ }^{44}$. Nevertheless, the above hypothesis is flawed in that apparently Boniface IX did not plan on making Świętosław an auxiliary bishop in Prague, since he was emphatic about Bishop of Łuck's duty to reside in the diocese, and banned him from performing any episcopal functions outside its area - as he had done 4 years before with Grzegorz Buczkowski's preconisation ${ }^{45}$. Could the pope's decision be explained, for example, by internal conflicts among Bohemia's lay and ecclesiastical elites, the upshot of which would be loss of support for Świętosław on the part of Wenceslaus IV's circle or even the Archbishop of Prague? As a consequence, Wenceslaus de Applot could have been reappointed to the position of an auxiliary bishop. According to Eva Doležalova, Wenceslaus, a Dominican, had already played a similar role in the case of Johannes von Jenstein, back in the late 14th century ${ }^{46}$. In addition, Václav Vladivoj Tomek states that Wenceslaus de Appot was Auxiliary Bishop of Prague also in the years 1402-1403, after the death of Olbram von Škvorec (1396-1402) ${ }^{47}$. If this was indeed the case, we may theoretically assume that in the light of Świętosław's failed nomination to the auxiliary bishopric in Prague as a titular Bishop of Łuck, the pope's entourage decided to still follow through with Świętosław's preconisation, presumably due to his own influence or the influence of some patrons, unknown today. Therefore, in the absence of a possibility to act as an auxiliary bishop in Prague, the new bishops' duty to reside in the Łuck diocese was clearly emphasized, without considering further consequences.

44 W. Abraham, Poczatki arcybiskupstwa, p. 39; idem, Powstanie organizacji, p. 256 ff.; T.M. Trajdos, Kościót katolicki na ziemiach, pp. 214-215; idem, Miechowici na ziemi przemyskiej za panowania Wtadystawa Jagietty, Folia Historica Cracoviensia, 4-5 (1997-1998), p. 72.

45 Monumenta Vaticana res gestas Bohemicas illustrantia, No. 2197; BP, Vol. 3, No. 656, 951; Codex epistolaris Vitoldi Magni Ducis Lithuaniae 1376-1430, ed. A. Prochaska, Cracoviae 1882, No. 219; Bullarium Ordinis Fratrum Praedicatorum, opera Th. Ripoli magistri generalis editum, Vol. 2, Romae 1730, No. 136.

46 E. Doležalová, Svěcenci pražské diecéze, p. 113.

47 Dějepis města Prahy, Vol. V, p. 115. Bishop Wenceslaus died only after 1412. On Olbram von Škvorec, see Z. Hledíková, Olbram von Skvorec (+ 1402). 1396-1402 Erzbischof von Prag, [in:] Die Bischöfe des Heiligen Römischen Reiches, pp. 592-593; A. Frind, Die Geschichte der Bischöfe und Erzbischöfe von Prag, pp. 106-107. 
Still, it is difficult to prove that this actually happened without answering another question: were these documents prepared by the Roman Curia according to a certain convention? Nevertheless, it is worth noting that, according to the sources, Świętosław held himself to be an actual rather than titular Bishop of Łuck, and he indeed was also a suffragan of Jakub Strepa, Archbishop of Halicz ${ }^{48}$. He did not interpret the pope's words on the duty of residence as a conventional formula but tried to carry it out thoroughly. He must have been also aware of the consequences of his actions, as well as Witold's and Grzegorz Buczkowski's reactions to them.

It seems that the second possibility, suggesting the Roman Curia's ignorance of the Church's position in Ruthenia coupled with the support, probably by Bohemian circles, of the first Bishop of Łuck, opens multiple routes of interpretation, yet none of the above hypotheses seems convincing.

There is also a third possibility, linking Świętosław's preconisation to support from Władysław Jagiełło, against Witold's ecclesiastical policyand it seems the most logical one. As already mentioned, this has been repeatedly referred to in the Polish historiography, and most convincingly voiced in the recent years by Tadeusz Traj$\operatorname{dos}^{49}$. Let us assume that Świętosław's nomination for the bishopric of Euck in 1404 was supported by Jagiełło and aimed at extending his influence over the Łuck region, contrary to Witold's interests. If so, Jagiełlo must have known, or at least heard about Świętosław before. Assuming it was unlikely for Świętosław to have arrived in the newly-established Carmelite monasteries in Poland in the company of other Prague monks, he might have presented himself at the Krakow court as a brilliant coordinator of the undertaking, perhaps with some experience gained during his missions in Ruthenia. Nevertheless, the establishment of the Euck diocese, separately from the Włodzimierz diocese, was a success of the Crown in its dispute with Lithuania over the title to Volhynia. The royal policy in this matter was likely supported by Jakub Strepa, Archbishop of Halicz, owing to whom the king could have extended his metropolitan authority over a substantial part of the disputed Ruthenia. Indeed, Grzegorz Buczkowski showed no will of subordination to Jakub Strepa, and he os-

\footnotetext{
48 W. Abraham, Jakub Strepa arcybiskup halicki, p. 110, No. X.

49 E.g. T.M. Trajdos, Kościół katolicki na ziemiach, pp. 79-80; idem, U zarania, pp. 216-217; idem, Polityka króla Wtadystawa, p. 333; cf. B. Kumor, Organizacja diecezji litewskich, p. 79; J. Drabina, Papiestwo - Polska, pp. 38-39; J. Nikodem, Witold, p. 439; K.R. Prokop, Sylwetki biskupów tuckich, pp. 24; J. Pietrzykowski, Organizacja Kościoła łacińskiego na terenach wschodnich Rzeczypospolitej w początkach unii brzeskiej, [in:] Rola Kościoła w dziejach Polski. Kościoły w Rzeczypospolitej, ed. J. Krochmal, Warsaw 2017, p. 126.
} 
tentatiously appeared at the metropolitan council of Gniezno called by Mikołaj Kurowski in $1406^{50}$ instead of the metropolitan council of Halicz convened by Jakub Strepa, which was held almost at the same time and attended by Świętosław who made his attestation in the archbishop's document of 19 June of the same year ${ }^{51}$.

In these assumptions, a conclusion must be drawn that in his letter of 1410 , Władysław Jagiełło, as suggested by Grażyna Klimecka, wrote a downright lie by calling Świętosław a usurper and concealing his former support for the first Bishop of $\operatorname{tuck}^{52}$. We may also assume that he did so to strengthen his ties with Witold, facing the prospect of a war with the Teutonic Knights ${ }^{53}$. In any case, it seems surprising that Jagiełło would not voice his protest in the matter for another 5 years while he remained in Roman Obedience. Indeed, he could have expressed his discontent by writing to as many as 3 subsequent popes, i.e. Boniface IX (at the end of his pontificate), as well as two of his successors: Innocent VII and Gregory XII. Instead, he did this only by notifying of Świętosław's activities one of the Pisan popes (most probably Alexander V or John XXIII) to whose authority he had been subjected since $1409^{54}$. Let us thus take a closer look at the letter: its opening already confirms the role played by Witold in the Church's growth in Ruthenia as a founder and benefactor of the bishopric of Włodzimierz placed under the authority of Grzegorz Buczkowski. Jagiełło quite frankly wrote:

For the growth of faith and salvation of faithful souls, the Honourable Duke Alexander, also known as Witold, His Highness Duke of Lithuania, my dearest brother, acting on my advice and with my support, founded, furnished and

50 See e.g. T. Graff, Episkopat, p. 115. If, when fighting Świętosław, Buczkowski acted against the Crown's ecclesiastical interest, it would be interesting to know how Mikołaj Kurowski Archbishop of Gniezno, who represented the Crown's interests, reacted to Buczkowski's presence at the council. In any event, we do not have any reports of lack of acceptance of Buczkowski's actions on Kurowski's part. Perhaps the consolidation of the position of Jakub Strepa, another competing metropolitan archbishop, by attaining a new suffragan bishop represented by Świętosław, was also contrary to Kurowski's interests.

51 W. Abraham, Jakub Strepa arcybiskup halicki, p. 110, No. X.

52 G. Klimecka, Z historii tworzenia języka, No. 25, pp. 84-85.

53 See e.g. J. Nikodem, Witold, pp. $276 \mathrm{ff}$.

54 For more details on the circumstances surrounding Poland's transition to the authority of the Pisan popes see: T. Graff, Stosunki Polski ze Stolica Apostolska na tle wyboru pseudopapieży od czasów wczesnopiastowskich do soboru pizańskiego - wybrane aspekty i zarys problematyki, Zeszyty Naukowe Uniwersytetu Jagiellońskiego. Prace Historyczne, 131 (2004), pp. 68-75; idem, Episkopat, p. $192 \mathrm{ff}$. 
erected the cathedral in Włodzimierz, the diocese of which he established according to our wish. Grzegorz, the current bishop, who was canonically consecrated in the Holy See, the lawful (true) incumbent of the bishopric, duly holds and wields authority in the church [translation ${ }^{55}$.

Jagiełło's introduction leads to a conclusion that the Włodzimierz church, operating among Eastern Orthodox schismatics, required special attention so that no unseemly thing tarnished its reputation ${ }^{56}$. Jagiełlo was more specific later on, enumerating things which in his opinion interfered with the smooth operation of the Włodzimierz church under Grzegorz Buczkowski, and which were contrary to the royal activities aimed at establishing the union. Namely, the first obstacle was the conduct of some nondescript monks who:

wish to abandon the monastic yoke and free themselves from obedience towards their superiors; such people did not benefit from the knowledge of literature, nobleness of customs or the just and righteous way of life, but having caused an event spreading corruption among people, they strive to sow discord in churches by delivering their sermons to the folk, [the discord] which we tolerate for the glory of God, for the genuineness of the holy union, and they complain that [the churches] belong to them, not to God, breaking what they cannot build, failing to reap what they cannot sow, indulging themselves to lead lives of schismatics before the ungodly [translation $]^{57}$.

It is hard to say which monks Jagiełło had in mind but perhaps a letter written several years later by Witold to Pope Martin V of 1418 is a key to solving the mystery. In it, the Grand Duke mentioned Maciej, a Dominican in a jurisdictional dispute in Łuck with Grzegorz Buczkowski, a former Łuck prior ${ }^{58}$. We may therefore suppose that some of Łuck's mendicants, headed by Maciej and in conflict with their former prior, supported Świętosław, the new Bishop of Łuck for a period of time (as Hińca, the Łuck parish priest, probably did), at the same time failing to recognise the jurisdiction of the Bishop of Włodzimierz in $\mathrm{Euck}^{59}$.

\footnotetext{
55 G. Klimecka, Z historii tworzenia języka, No. 25, p. 84.

56 Ibidem.

57 Ibidem, pp. 84-85.

58 Codex epistolaris saeculi decimi quinti, Vol. 2, ed. A. Lewicki, Cracoviae 1891, No. 89; cf. T.M. Trajdos, Kościót katolicki na ziemiach, pp. 79-80.

59 W. Abraham, Buczkowski Grzegorz, p. 87.
} 
Another obstacle in the regular operations of the Włodzimierz diocese, referred by Jagiełlo in his letter to the pope, was Świętosław as the Bishop of Łuck and his deeds. Allegedly, Świętosław was insolent enough to usurp the title of the Bishop of Euck and appropriate the episcopal chair (kathedram episcopalem pro se attrahyt et usurpat) which was dangerous in that the cathedral was the basis of the entire income of the Włodzimierz bishopric, as well as the seat and place of residence of church hierarchs nominated by Witold ${ }^{60}$. The king requested the pope to take all the required steps to which he was entitled in such matters ${ }^{61}$. Jagiełlo directly indicated what was to be done, expressing his wish:

so that $[. .$.$] the Włodzimierz church newly erected by us does not become$ divided and the past dissent is alleviated under a single caring shepherd, and Świętosław, the disobedient bishop causing the dissent [must be forced] to remain forever silent [translation $]^{62}$.

It transpires that the letter was written in connection with the mission of Piotr Wysz, Bishop of Krakow, who made an appearance in the Council of Pisa in 1409 as an ambassador for the king, Mikołaj Kurowski, Archbishop of Gniezno and the Krakow University ${ }^{63}$. Thus, Grażyna Klimecka's findings can be made more precise and a conclusion can be drawn that the letter was written in the same year. Moreover, if we accept that it was Jagiełło who contributed to Świętosław's appointment to the episcopal cathedral in Euck in 1404, we must also assume that he did not hesitate to lie to Alexander V. It was, in fact, a double lie: first, the king passed over his recent support for Świętosław; secondly, he called the Łuck ordinary a usurper, in spite of being well aware that the latter had been nominated for the episcopal office by Boniface IX in accordand with the canon law. If this was indeed the case, the king had nothing to fear as far as the Pisan pope was concerned, since he was perfectly

60 G. Klimecka, Z historii tworzenia języka, No. 25, p. 85: Prout quidam Svanthoslaus pro episcopo Lucensi se gerens propria temeritate episcopatum Vladimiriensem scindere cupiens in Luczko, kathedram episcopalem pro se attrahyt et usurpat, ubi eciam medulla et communi omnium proventum pro ecclesia Vladimiriensi, ymo et sessio, et domicilium episcoporum per eundem fratrem nostrum, dominum Alexandrum alias Vitoldum deputata sunt pro ipsius episcopi comodosa et pacifica mansione.

61 Ibidem.

62 Ibidem: Quomodo predicta ecclesia Vladimiriensis novella et per nos noviter erecta non scindatur, et quod sub uno provido pastore antiqui scisma sopiatur Svanthoslaum predictum episcopum inparentem perpetui silencii scismam remanentes.

63 W. Abraham, Reforma na soborze w Pizie 1409 r. i udziat w niej przedstawicieli Kościoła Polskiego, Polonia Sacra, 3 (1919), pp. 121-122. 
aware that the pope elected by the Council of Pisa would not be too inquisitive in the matter. Its first and foremost aim was to attain and, later on, maintain the Polish-Lithuanian obedience. Therefore, Jagiełło hoped that Świętosław’s dispute with Grzegorz Buczkowski would be resolved as the king himself intended. Indeed, soon after electing Alexander V, the pope ordered the royal ambassador, Piotr Wysz, Bishop of Krakow, to take on the role of a judge in the said dispute ${ }^{64}$. Grzegorz Buczkowski was also present at the Council of Pisa and did his best to discredit his adversary, with whom, according to Władysław Abraham, he had been involved in a lawsuit before the Roman curia for several years ${ }^{65}$. Alexander V's favourable disposition towards Buczkowski is exemplified by granting an indulgence privilege for Sts Peter and Paul's Cathedral in Włodzimierz on 3rd August $1409^{66}$.

Remarkably, on the very same day, the pope ordered the Bishop of Krakow to resolve the dispute between Świętosław and Buczkowski. At the same time, Alexander V implied that Świętosław was an usurper, and his adversary was in the right. The pope wrote that his decision to nominate Piotr Wysz arbitrator of the dispute was a direct response to a complaint by Buczkowski, who compiled a detailed list of property owned by the Włodzimierz church and granted by Witold, which included Łuck. Meanwhile, Świętosław insisted (apparently falsely) that it was Łuck which should hold the title of an episcopal see, as this allegedly was the way in which the town had been founded. In this context, Świętosław was believed to interfere with Grzegorz Buczkowski's duties in the area of the latter's jurisdiction, and even resort to some unspecified abuse and violence. Obviously, the matter had already been investigated by Henry, Bishop of Sabina, who heard both sides of the contention ${ }^{67}$. Does it imply that Świętosław appeared in person before the arbitrator or at least

64 W. Abraham, Sprawozdanie z poszukiwań $w$ archiwach i bibliotekach rzymskich do dziejów Polski w wiekach średnich za lata 1899-1913, [in:] Archiwum Komisji Historycznej, Series 2, Vol. I, Krakow 1923, pp. 58-60, No. 2; BP, Vol. 3, No. 1216; Pontificia Commissio ad Redigendum Codicem Iuris Canonici Orientalis. Fontes, coll. A.L. Tăutu, Vaticanis 1971, Series Świętosław 3, XIII/ 2, 101.

65 W. Abraham, Udziat Polski w soborze pizańskim, pp. 137, 148-149.

66 The Library of Polish Academy of Sciences (PAN) and the Polish Academy of Learning (PAU) in Krakow, Roman Files, MS 8495, pp. 176-177; Przywilej odpustowy papieża Aleksandra $V$ dla katedry łacińskiej we Włodzimierzu wotyńskim z 3 sierpnia 1409 r., issued by W. Abraham, Kwartalnik Historyczny, 29 (1915), p. 296; BP, Vol. 3, No. 1217; W. Szymborski, Odpusty w Polsce średniowiecznej, Krakow 2011, p. 370, No. 553; W. Abraham, Buczkowski Grzegorz, p. 87; K.R. Prokop, Sylwetki biskupów tuckich, p. 25. 
sent his representative? This most certainly did happen, since Grzegorz Buczkowski, albeit appreciative of the force of his adversary's arguments, in his complaint against Świętosław emphasized that one could only gain real insight into the conflict by being present in Ruthenia, not in the Roman Curia. Taking all of this into consideration, Alexander V ordered Piotr Wysz, a person with better knowledge of the nature of the dispute, to finally settle the matter ${ }^{68}$. Therefore, the pope gave the Bishop of Krakow the following instructions:

if, after summoning the said Świętosław and others, which need to be summoned, by your detailed investigation - on the basis of the authorisation granted above - of the matters at hand, it becomes obvious to you that the Duke set aside the city of Łuck, as mentioned before, to hold spiritual jurisdiction for the church in Włodzimierz and its bishop, as the case may be at a given time, and also [if it becomes apparent] that there was no cathedral church founded in the city of Łuck and no evidence to the contrary has ever existed, and no temporary episcopal see has ever existed in the city, we entrust your conscience in such matters to order Świętosław to remain forever silent on the anguish and unrest that has been caused, and not hesitate to free bishop Grzegorz from any obstacles presented by Świętosław, acting under the same authorisation, and to order Świętosław to reimburse the expenses incurred in this matter by bishop Grzegorz, and to make him effectively compensate for the matters to the bishop, subject to ecclesiastical penalty, with no possibility of appealing against it, under the same authorisation as mentioned above.

Otherwise, having listened to both parties' [own opinions] as to what would be just, resolve the matter, without the possibility of appeal, so that what you decide shall be permanently followed, subject to the same penalty; also, make the appointed witnesses give true evidence, provided that they renounce their favouritism, hatred or fear [translation $]^{69}$.

At the end of his letter to Wysz, the pope once again underlined the expected judgement i.e. one that would be to the best of Witold's interest:

However, we request [...] [if] you order [...] Świętosław to remain silent in the above matter, to ensure that the Duke's aforementioned foundation and endowment - exactly as mentioned - is confirmed, and [such orders are] followed, with all the consequences [translation $]^{70}$.
68 Ibidem.
69 Ibidem.
70 Ibidem. 
What follows, therefore, is that Alexander $\mathrm{V}$ was inclined to resolve the matter unfavourably for Świętosław, and even avoided calling him a bishop. It even seems that the pope's decision echoed the message of the royal letter in which the king asked the Holy Father to punish Świętosław, a troublemaker and usurper, and to order him to remain silent in the contentious matter ${ }^{71}$. Unfortunately, we do not know if the case was ultimately heard before the court. Most probably it was not, both because of Wysz's illness ${ }^{72}$ and the fact that Świętosław either died or left the diocese for Prague at that time (?). In any case, from that point onwards the sources do not reveal any information on Świętosław ${ }^{73}$.

At this conjecture, it is interesting whose interest was supported by King Jagiełło in the conflict between Buczkowski and Świętosław: Poland's or Lithuania's? Świętosław's actions evidently harmed Witold's ecclesiastical policy and were in line with both archbishop Jakub Strepa's and Poland's interest in the contentious region of Volhynia. Accordingly, assuming Jagiełło's initial support for Świętosław's nomination to the diocese of Łuck in 1404, we should also investigate factors which caused the king to change his mind 5 years later. It seems that the answer is straightforward: as already mentioned, the reason behind this change was the need to strengthen the alliance with Witold in the face of the looming conflict with the Teutonic Knights. This was not the best time to engage in disputes on the authority over the Church in Ruthenia, since both countries had to face an epoch-making challenge $^{74}$. Furthermore, Jagiełło identified himself with Lithuania all his life, and as such he often acted against the interest of Poland, e.g. initially supporting Witold's coronation plans, or temporarily accepting Švitrigaila 's unlawful rise to the throne ${ }^{75}$.

71 G. Klimecka, Z historii tworzenia języka, No. 25, p. 85.

72 Ioannis Dlugossii Annales, lib. X-XI, Varsaviae 1997, pp. 24-25.

73 See e.g. T. Graff, Świętosław, p. 548; K.R. Prokop, Biskupi pomocniczy w diecezjach polskich, pp. 340-341; idem, Sylwetki biskupów tuckich, pp. 28-29.

74 For more details on the subject, see e.g. S. Jóźwiak, K. Kwiatkowski, A. Szweda, S. Szybkowski, Wojna Polski i Litwy z Zakonem Krzyżackim w latach 1409-1411, Malbork 2010.

75 G. Błaszczyk, Burza koronacyjna. Polska-Litwa 1429-1430, Poznań 1998; T. Graff, Działalność polityczna Zbigniewa Oleśnickiego i polskiej hierarchii kościelnej w dobie tzw. burzy koronacyjnej, Folia Historica Cracoviensia, 14 (2008), pp. 75-85; J. Nikodem, Spory o koronację księcia Litwy Witolda $w$ latach 1429-1430, Part I: Burza koronacyjna $w$ relacji Jana Dtugosza, Lituano-Slavica Posnaniensia. Studia Historica, 6 (1994) [1995 edition], pp. 55-75 and Part II. Próba rekonstrukcji wydarzeń, Lituano-Slavica Posnaniensia. Studia Historica, 7 (1995) [1997 edition], pp. 155-171; idem, Wyniesienie Świdrygiełly na Wielkie Księstwo Litewskie, Białoruskie Zeszyty Historyczne, 19 (2003), pp. 5-31; A. Lewicki, Powstanie Świdrygietty. Ustęp z dziejów unii Litwy 
Nevertheless, if Witold indeed contemplated the independence of the Włodzimierz bishopric from Polish influence and its subordination to the prospective Vilnius Metropolis, his plans must have failed miserably. Namely, in 1412 in a bull issued at Jagiełło's explicit request, Pisan pope John XXIII moved the seat of the metropolis from Halicz to Lwów and listed the suffragan bishops of the Archbishop of Lwów, stating that the list included the Bishop of Włodzimierz (Ad provinciam Leopoliensem eccl. Premissliensis, Chelmensis, Camenecensis, Wlodimiriensis, Seretensis et Kyouiensis pertinere teneantur $)^{76}$. Still, both Buczkowski and Witold were glad to see that the Bishop of Łuck was missing from the list. It did not matter whether Świętosław was alive or dead back then; the very fact that no successor of Świętosław was nominated and the bishopric of Łuck was not mentioned next to the Włodzimierz diocese reinforced the integrity of Grzegorz Buczkowski's ecclesiastical power in Volhynia. The disagreement caused by the Bishop of Łuck's appointment in 1404 was symbolically resolved as late as in 1425; after Grzegorz Buczkowski's death Pope Martin V moved the episcopal see from Włodzimierz to Łuck, actually recognising the existence of the Euck bishopric, as an entity subordinate to the Lwów Metropolis and headed by a new hierarch, Andrzej of Płońsk ${ }^{77}$.

To sum up this part of this study, we may conclude that Jagiełlo contributed to Świętosław's incumbency of the Łuck bishopric, in this way furthering Poland's interests. However, several years later, for the purpose of strengthening his alliance with Witold, in a letter to Alexander V, he presented the Bishop of Łuck as a usurper.

\section{Conclusions}

In the light of the above discussion, the scenario of Jagiełto's initial support for Świętosław's candidature for the Euck bishopric in 1404 appears most likely, certainly more likely than the bishop's preconisation in the Polish-Lithuanian monarchy without the king's knowledge or consent. It was either owing to the pontifical pa-

z Koroną, Rozprawy Akademii Umiejętności Wydz. Hist.-Filoz., 29 (1892), pp. 128-516.

76 BP, Vol. 3, No. 1398; Theiner, Vol. 2, Romae 1861, No. 8.

77 BP, Vol. 4, ed. et cur. I. Sułkowska-Kuraś, St. Kuraś, H. Wajs, Romae 1992, No. 1640; J. Lisowski, De servitiis communi et minuti episcoporum Poloniae, Romae 1982, No. 108; Excerpta ex libris manu scriptis Archivi Consistorialis Romani, [in:] Analecta Romana, ed. I. Korzeniowski, Scriptores Rerum Polonicarum, Vol. 15, Cracoviae 1894, No. 14; cf. K.R. Prokop, Sylwetki biskupów tuckich, p. 29; T. Graff, Episkopat, p. 166; B. Modzelewska, Eucka diecezja katolicka, [in:] Encyklopedia katolicka, Vol. XI, ed. E. Ziemann, Lublin 2006, col. 589-590. 
tronage or the Bohemian influences taking advantage of the unstable position of the Church in Ruthenia at that time. However, the connections (if any) that Świętosław had with the Polish royal court remain a mystery, even more so thatthere is overwhelming evidence that in the previous years his main connections were mainly with the archdiocese of Prague and the Prague Carmelite monastery. It is rather unlikely that Świętosław arrived in Poland with the first monks brought from Prague by Jagiełlo and Jadwiga, although he may have been known at the Polish court, e.g. as a representative negotiating the conditions of the monasteries' endowment by the Order. For some time, he could have been also involved in the missions in Ruthenia. In any case, Świętosław's work as the Bishop of Łuck was certainly unacceptable to the Bishop of Włodzimierz and primarily to Witold, a patron of the latter. We assume that, albeit contrary to Poland's interest, Jagiełło had to relinquish his support for Świętosław and deny before the Pisan pope any relations with the bishop when faced with the necessary close political alliance with Witold, aware of the imminent conflict with the Teutonic Order. In a world of three popes ruling the Catholic church at the same time, the Pisan popes, content with securing Poland's obedience in 1409, probably felt it was in their interest not to ask the Polish king about the underlying reasons for Świętosław's disfavour with the king. Consequently, although Świętosław was not a usurper but the Bishop of Łuck duly appointed by Pope Boniface IX, as the king and his officials knew perfectly well, after several years Jagiełło started to treat the bishop as a usurper to advance his own political interest. As a result, in the context of a weak and divided papacy, the fate of the hierarch residing in the Euck diocese was sealed. It was probably his own death or escape (perhaps to the Carmelite monastery in Prague) which saved him from Piotr Wysz's accusations.

Translated by Tomasz Wolski

\section{Summary}

The author analyses the ecclesiastical career of Bohemian Carmelite Świętosław who became the first bishop of Łuck in 1404. His appointment caused a conflict with Grzegorz Buczkowski, Bishop of Włodzimierz, and objection of Grand Duke Witold. It also destabilised the position of the Church in Volhynia. One of the article's objectives is to explain who was Świętosław's patron and who interceded with the Roman Curia for his promotion to the chair of bishop. In the light of the above, the author investigates 3 main scenarios: 1 . the pope's patronage, 2. lack of in-depth knowledge on the part of the pope and the Roman $\mathrm{Cu}$ ria about the Church's position in Ruthenia coupled with the support of Bohemian elites or 
the court of Wenceslaus IV, and 3. Władysław Jagiełło's patronage, with the emphasis placed on the significance of broader interpretation of the royal letter from the so-called Formularz Ciechanowski in which Świętosław was called a usurper.

Translated by Tomasz Wolski

Dr hab. Tomasz Graff

Katedra Historii Starożytnej i Średniowiecznej w Instytucie Historii UP JPII ul. Kanonicza 9

31-002 Kraków

e-mail: grafftomasz@gmail.com

Nadesłany 11 XI 2019

Nadesłany po poprawkach recenzyjnych 30 XII 2019

Zaakceptowany 15 I 2020 